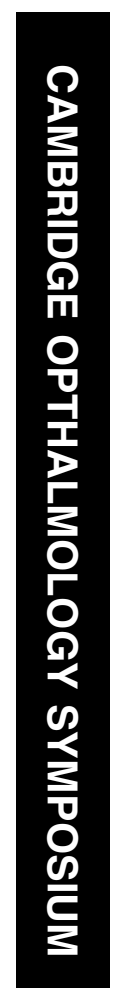

\title{
Antibody-based immunosuppressive agents for corneal transplantation
}

\begin{abstract}
The progress in antibody engineering over the last 20 years has created the tools for the development of novel antibody-based drugs and constructs, such as small antibody fragments, suitable for topical administration. In rheumatology, oncology, transplantation medicine and ophthalmology, therapeutic antibody constructs, and antibody fragments have been responsible for the clinical progress seen over the last decade. Although antibodybased therapies have become a wellestablished immunosuppressive option in solid organ transplantation, there are only very few reports with regard to corneal transplantation. The following review explains some of the important aspects of engineered antibody-based therapeutic agents and summarises the current use of such immunosuppressive therapies in transplantation medicine and corneal transplantation.

Eye (2009) 23, 1962-1965; doi:10.1038/eye.2008.384; published online 9 January 2009
\end{abstract}

${ }^{3}$ Department of Ophthalmology, Flinders University of South Australia, Adelaide, Australia

Correspondence:

MA Thiel,

Department of Ophthalmology, Cantonal Hospital Lucerne, 6000 Lucerne 16, Switzerland.

Tel: + 4141205 3301;

Fax: 41412053404.

E-mail: Michael.Thiel@ ksl.ch

Received: 2 October 2008 Accepted in revised form: 2 October 2008

Published online: 9 January 2009
MA Thiel ${ }^{1,2}$, C Kaufmann², DJ Coster ${ }^{3}$ and KA Williams ${ }^{3}$

better-tolerated and more effective immunosuppressive antibodies. Over the last decade, these antibody constructs have become an important tool in organ transplantation with up to $80 \%$ of recipients being treated with such antibody-based agents. ${ }^{1}$ There are growing efforts to design antibody-based drugs for ocular diseases. This review summarises some important aspects of antibody-based immunosuppressive agents in transplantation from an ophthalmic perspective.

\section{Antibody constructs}

There has been enormous progress in the techniques of antibody engineering over the last two decades. ${ }^{2}$ Originally, immunosuppressive polyclonal and monoclonal antibodies were generated either by immunizing animals or by culturing murine hybridoma cell lines. These cumbersome techniques have been replaced by DNA engineering combined with very effective antigen-binding selection techniques, such as phage or ribosomal display. ${ }^{3}$ The modern techniques in antibody engineering that have evolved over the last two decades allow the customised design of chimeric, humanized, or even fully human antibodies from synthetic DNA libraries (Figure 1). In addition, antibody engineering allows for the construction of small antibody fragments, such as single-chain variable region $(\mathrm{scFv})$ fragments. ${ }^{4} \mathrm{ScFv}$ fragments have approximately half the molecular size of regular antigen-binding fragments (Fab), which enable the former to penetrate into the anterior chamber and the vitreous when administered topically. ${ }^{5-7}$

In contrast to IgG antibodies, which have two antigen-binding sites per molecule, Fab and $\mathrm{scFv}$ antibody fragments have a single-binding site, permitting monovalent binding only. Divalent binding allows formation of a tighter bond and cross-linking of non-soluble antigens, 

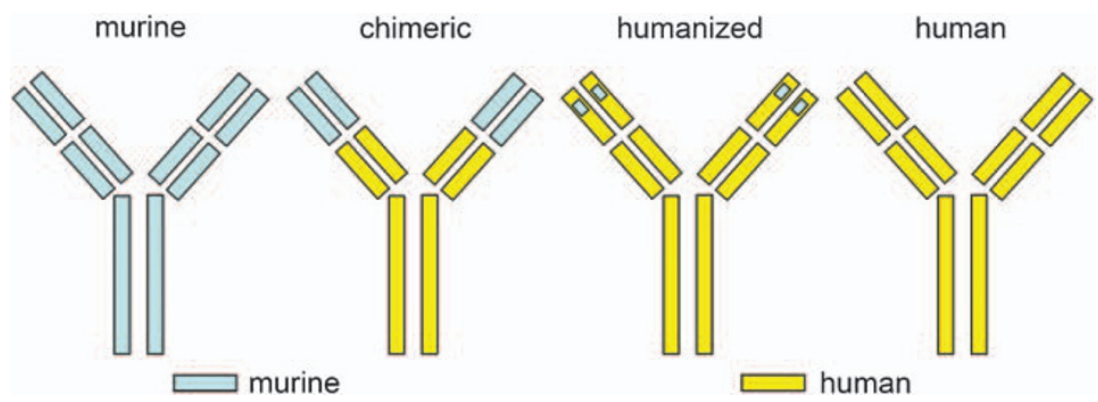

Figure 1 Various composites of human and non-human elements in antibody constructs.

such as receptors on cell surfaces. For soluble antigens, such as tumour necrosis factor- $\alpha$ (TNF- $\alpha$ ) or vascular endothelial growth factor (VEGF), divalent binding by a single large antibody has a similar effect to monovalent binding by twice as many small antibody fragments. This is shown by the similar clinical effect observed with the use of the divalent bevacizumab (avastin, humanised antibody) compared with the monovalent ranibizumab (lucentis, Fab fragment) in age-related macular degeneration. ${ }^{8}$ On the premise that antibody-based immunosuppressive therapies in corneal transplantation should be administered topically to reduce the risk of systemic side effects, the ideal target antigens are small soluble antigens, which can be blocked by small monovalent antibody fragments.

\section{Antibody-based immunosuppressive therapies in transplantation}

Although the ultimate goal in transplantation immunology remains the induction of donor-specific tolerance in the recipient, the realistic goals of antibodybased immunosuppressive therapies today are more modest to improve the long-term graft survival rate by slowing or reducing sensitisation of the recipient to the donor, to reduce the dose and thereby the side effects of conventional immunosuppressive therapies, or to rescue grafts from acute or chronic rejection. As the immune processes associated with these aims differ, the choice of an individual antibody strongly depends on the specific goal, the timing, and the organ being transplanted.

The key player in the process of graft rejection is the $\mathrm{T}$ lymphocyte, and therefore various receptors on $\mathrm{T}$ cells are the targets of most antibody-based therapies (Figure 2). The T-cell receptor and two adjacent molecules, CD3 and CD4, are involved in antigen recognition (signal 1). The receptors CD80 and CD86 on antigen-presenting cells and the corresponding receptors CD28 and CTLA4 are responsible for the activation of the $\mathrm{T}$ cell (signal 2). Once activated, interleukin 2 (IL-2) secreted by the $\mathrm{T}$ cell serves as an autostimulant, further activating the T cell through the IL-2 receptor (IL-2R,

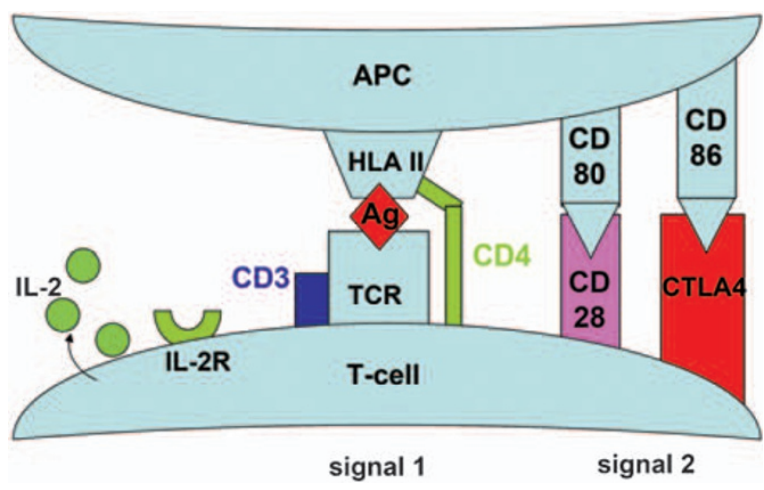

Figure 2 Receptors involved in the interaction between the $\mathrm{T}$ lymphocyte and the antigen-presenting cell (APC). TCR = T-cell receptor, $\mathrm{Ag}=$ antigen, HLA = human leukocyte antigen, $\mathrm{IL}=$ interleukin, $\mathrm{CD}=$ cluster of differentiation, CTLA $4=$ cytotoxic T-lymphocyte antigen 4.

signal 3). All three signals are required to stage a normal T-cell response to transplantation antigens (Table 1).

\section{Antibody therapies during the induction phase}

The use of antibody-based therapies during the induction phase of an immune response is designed to increase the long-term graft survival by modifying the process of donor-specific sensitisation at the time of transplantation. Today, in organ transplantation, the most common therapeutic strategies during the induction phase are anti-IL-2R antibodies. There are two commercially available anti-IL-2R antibodies: basiliximab and daclizumab. Antibody names featuring the suffix '...x....mab' refer to the chimeric antibodies, whereas those featuring the suffix '...$z \ldots$ mab' refer to the humanised antibodies. Both anti-IL-2R antibodies have been used successfully in renal, lung, and liver transplantations. ${ }^{8}$ The concept of anti-IL-2R antibody therapies are primarily to target the initial wave of T cells activated by migrating APC from the donor organ to the recipient and by chemokines liberated from vascular endothelium of the graft. This early wave of T-cell activation is initiated primarily by reperfusion injury of 
Table 1 Immunosuppressive antibodies and constructs, and the experience in ophthalmology

\begin{tabular}{|c|c|c|c|}
\hline Treatment strategy & $\begin{array}{l}\text { Target antigen/ } \\
\text { cell }\end{array}$ & Antibody & Experience in ophthalmology \\
\hline \multirow[t]{3}{*}{ Induction therapy } & CD25/T cells & Daclizumab & No published reports in corneal transplantation \\
\hline & CD25/T cells & Basiliximab & One RCT indicating equivalent effect to systemic cyclosporine \\
\hline & CD52/T cells & Alemtuzumab & $\begin{array}{l}\text { Two case reports with preventative and therapeutic use in corneal } \\
\text { graft rejection }\end{array}$ \\
\hline \multirow[t]{2}{*}{ Maintenance therapy } & $\begin{array}{l}\text { CD80, CD86/ } \\
\text { APC }\end{array}$ & Abatacept & Weak effect in animal models of corneal transplantation \\
\hline & $\begin{array}{l}\text { CD80, CD86/ } \\
\text { APC }\end{array}$ & Belatacept & No published reports in corneal transplantation \\
\hline $\begin{array}{l}\text { Rescue treatment for graft } \\
\text { rejection }\end{array}$ & $\begin{array}{l}\mathrm{CD} 3 / \mathrm{T} \text { cells } \\
\mathrm{TNF} \alpha\end{array}$ & $\begin{array}{l}\text { Muronomab/ } \\
\text { ATG } \\
\text { Infliximab }\end{array}$ & $\begin{array}{l}\text { No published reports in corneal transplantation } \\
\text { Effective in uveitis, no published reports in corneal transplantation }\end{array}$ \\
\hline
\end{tabular}

the transplanted organ. ${ }^{1}$ The protective effect of these antibodies depends on starting treatment early, that is, before donor $\mathrm{T}$ cells reach draining lymph nodes (eg, dosing on day 0 and +4 with respect to the day of transplantation). Although basiliximab and daclizumab are very effective in reducing the risk of organ graft rejection during the first year, they are ineffective for the treatment of acute graft rejection. Both antibodies are very frequently prescribed in organ transplantation, as they are well tolerated with very few side effects. ${ }^{9}$ As there are no donor derived $\mathrm{T}$ cells migrating from the donor cornea to the recipient lymph node, the conceptual argument for the use of these antibodies in corneal transplantation is less evident. So far, there is one case series and a small randomised controlled trial reporting the effect of basiliximab in corneal transplantation. ${ }^{10,11}$ In an uncontrolled group of seven high-risk keratoplasty patients treated with basiliximab combined with cyclosporine, no rejection was observed. ${ }^{10}$ In a small randomised controlled trial, a 2-year graft survival did not differ between high-risk patients treated with basiliximab or cyclosporine. However, there were fewer side effects reported with basiliximab than with cyclosporine. ${ }^{11}$

A third antibody used in the induction phase is the anti-CD52 antibody alemtuzumab (Campath-1H; humanised antibody). ${ }^{12}$ CD52 is a receptor on T cells, B cells, monocytes, and natural killer cells. Its function is unknown. Treatment with alemtuzumab results in prolonged, severe T-cell depletion. Although this treatment is highly effective in reducing the risk of shortand long-term graft rejection in kidney, lung, and liver transplants, its associated comorbidity seems to justify its use in corneal transplantation only in special circumstances. So far, there are two case reports where alemtuzumab given at the time of corneal transplantation (one case) $)^{13}$ or during corneal graft rejection (two cases) ${ }^{14}$ resulted in a long-lasting graft survival.

\section{Antibody-based therapy during the maintenance phase}

CTLA4-Ig (abatacept and the affinity-matured belatacept) are antibody-based constructs combining the extracellular part of the immunomodulatory CTLA4 receptor with a human IgG Fc region. CTLA4-Ig was extensively tested in animal models of solid organ, skin, and corneal grafts during the 1990s. In rodents, a short treatment during the induction phase often resulted in a long-lasting donorspecific tolerance to skin, heart, and kidney grafts. The results reported with CTLA4-Ig in corneal transplants were generally less promising than in other transplant models. ${ }^{15-17}$ Phase III clinical studies with belatacept in human kidney recipients showed no effect in reducing the rate of acute graft rejection, but a considerably reduced risk of chronic graft rejection. ${ }^{18}$ However, the mechanisms involved in chronic renal graft rejection differ considerably from the mechanisms involved in corneal graft rejection. Thus far, there are no reports on the use of belatacept in corneal transplantation.

\section{Treatment of acute graft rejection with antibody-based therapies}

Antibody treatment of corticosteroid-resistant acute rejection of solid organ graft is most often based on ATG (antithymocyte globulin) or the anti-CD3 antibody muronomab $\left(\mathrm{OKT} 3{ }^{\circledR}\right) .{ }^{19}$ Anecdotal reports about OKT3 injections directly into the anterior chamber during acute corneal graft rejection described a devastating intraocular inflammatory response.

There are promising reports of the use of anti-TNF- $\alpha$ antibodies (infliximab) for the treatment of acute intestinal graft rejection ${ }^{20}$ and graft-versus-host disease. ${ }^{21}$ Systemically administered infliximab has been used successfully and with few side effects in severe uveitis. ${ }^{22}$ TNF- $\alpha$ is involved in cell death during corneal graft rejection, and blocking TNF- $\alpha$ may have a profound 
immunosuppressive effect. As TNF- $\alpha$ is a soluble antigen, it can be targeted by monovalent antibody fragments. ${ }^{7,23}$ Phase I and II trials with an anti-TNF- $\alpha$ $\mathrm{scFv}$ prepared for topical administration to the eye (ESBA105) are currently being undertaken.

\section{Summary}

Immunosuppressive antibodies are frequently used in organ transplantation. With the exception of anti-IL-2R antibodies, which may have some benefit in high-risk keratoplasty patients, the use of conventional antibodies is not justified routinely. Small antibody fragments, suitable for topical administration as eye drops, are currently under development and may in the future allow ophthalmologists to adopt some of the immunosuppressive strategies used in organ transplantation with fewer risks of systemic side-effects.

This manuscript has been presented at the Cambridge Ophthalmological Symposium, 3-5 September 2008 Financial interest: None.

\section{References}

1 Kirk AD. Induction immunosuppression. Transplantation 2006; 82: 593-602.

2 Chatenoud L. Monoclonal antibody-based strategies in autoimmunity and transplantation. Methods Mol Med 2005; 109: 297-328.

3 Zahnd C, Amstutz P, Pluckthun A. Ribosome display: selecting and evolving proteins in vitro that specifically bind to a target. Nat Methods 2007; 4: 269-279.

4 Filpula D. Antibody engineering and modification technologies. Biomol Eng 2007; 24: 201-215.

5 Thiel MA, Coster DJ, Standfield SD, Brereton HM, Mavrangelos C, Zola $\mathrm{H}$ et al. Penetration of engineered antibody fragments into the eye. Clin Exp Immunol 2002; 128: 67-74.

6 Williams KA, Brereton HM, Farrall A, Standfield SD, Taylor SD, Kirk LA et al. Topically applied antibody fragments penetrate into the back of the rabbit eye. Eye 2005; 19: 910-913.

7 Ottiger M, Thiel MA, Feige U, Lichtlen PD, Urech DM. Efficient intraocular penetration of topical anti-TNF-\{alpha\} single-chain antibody (ESBA105) to anterior and posterior segment without penetration enhancer. Invest Ophthalmol Vis Sci 29 August 2008 [e-pub ahead of print].

8 Takeda AL, Colquitt J, Clegg AJ, Jones J. Pegaptanib and ranibizumab for neovascular age-related macular degeneration: a systematic review. Br J Ophthalmol 2007; 91: 1177-1182.

9 Van Gelder T, Warle M, Ter Meulen RG. Anti-interleukin-2 receptor antibodies in transplantation: what is the basis for choice? Drugs 2004; 64: 1737-1741.

10 Schmitz K, Hitzer S, Behrens-Baumann W. [Immune suppression by combination therapy with basiliximab and cyclosporin in high risk keratoplasty. A pilot study]. Ophthalmologe 2002; 99: 38-45.

11 Birnbaum F, Jehle T, Schwartzkopff J, Sokolovska Y, Böhringer D, Reis A et al. Basiliximab following penetrating risk-keratoplasty - a prospective randomized pilot study. Klin Monatsbl Augenheilkd 2008; 225: 62-65.

12 Ciancio G, Burke III GW. Alemtuzumab (Campath-1H) in kidney transplantation. Am J Transplant 2008; 8: 15-20.

13 Newman DK, Isaacs JD, Watson PG, Meyer PA, Hale G, Waldmann H. Prevention of immune-mediated corneal graft destruction with the anti-lymphocyte monoclonal antibody, CAMPATH-1H. Eye 1995; 9(Part 5): 564-569.

14 Dick AD, Meyer P, James T, Forrester JV, Hale G, Waldmann $\mathrm{H}$ et al. Campath-1H therapy in refractory ocular inflammatory disease. $\mathrm{Br} J$ Ophthalmol 2000; 84: 107-109.

15 Thiel MA, Steiger JU, O'Connell PJ, Lehnert AM, Coster DJ, Williams KA. Local or short-term systemic costimulatory molecule blockade prolongs rat corneal allograft survival. Clin Experiment Ophthalmol 2005; 33: 176-180.

16 Comer RM, King WJ, Ardjomand N, Theoharis S, George AJ, Larkin DF. Effect of administration of CTLA4-Ig as protein or cDNA on corneal allograft survival. Invest Ophthalmol Vis Sci 2002; 43: 1095-1103.

17 Gebhardt BM, Hodkin M, Varnell ED, Kaufman HE. Protection of corneal allografts by CTLA4-Ig. Cornea 1999; 18: 314-320.

18 Vincenti F. Costimulation blockade in autoimmunity and transplantation. J Allergy Clin Immunol 2008; 121: 299-306; quiz 307-298).

19 Webster AC, Pankhurst T, Rinaldi F, Chapman JR, Craig JC. Monoclonal and polyclonal antibody therapy for treating acute rejection in kidney transplant recipients: a systematic review of randomized trial data. Transplantation 2006; 81: 953-965.

20 Pascher A, Klupp J, Langrehr JM, Neuhaus P. Anti-TNFalpha therapy for acute rejection in intestinal transplantation. Transplant Proc 2005; 37: 1635-1636.

21 Jacobsohn DA, Vogelsang GB. Anti-cytokine therapy for the treatment of graft-versus-host disease. Curr Pharm Des 2004; 10: 1195-1205.

22 Imrie FR, Dick AD. Biologics in the treatment of uveitis. Curr Opin Ophthalmol 2007; 18: 481-486.

23 Furrer E, Berdugo M, Stella C, Behar-Cohen F, Gurny R, Feige $U$ et al. Pharmacokinetics and posterior segment biodistribution of ESBA105, an anti-TNF-alpha single-chain antibody, upon topical administration to the rabbit eye. Invest Ophthalmol Vis Sci 29 August 2008 [e-pub ahead of print]. 